\title{
MODEL APLIKASI PURCHASING SYSTEM UNTUK MONITORING STOK DALAM MENGURANGI TINGKAT KERUGIAN
}

\author{
Junaidi $^{1}$ \\ Sutrisno $^{2}$ \\ Koriatul Janah ${ }^{3}$ \\ Dosen STMIK Raharja ${ }^{1,2,3}$ \\ STMIK Raharja Jurusan Teknik Informatika ${ }^{3}$ \\ Jl. Jendral Sudirman No. 40, Kota Tangerang, Banten ${ }^{1,2,3}$ \\ E-mail: junaidi@raharja.info ${ }^{1}$,sutrisno@raharja.info ${ }^{2}$,koriatul@raharja.info ${ }^{3}$
}

\begin{abstract}
ABSTRAK
Perkembangan teknologi informasi yang semakin pesat mampu memberikan dampak positif dan memacu pertumbuhan bisnis perusahaan secara cepat.Perusahaan yang bergerak dibidang ritel semakin dituntut untuk memberikan informasi dengan cepat dan tepat, apalagi hal-hal yang terkait dengan ketersediaan stok. Jumlah stok yang berkurang dari rata-rata kebutuhan akan menyebabkan tingkat kerugian yang disebabkan karena adanya pembatalan pesanan atau stok yang berlebih dari rata-rata penjualan juga mengakibatkan kerugian karena kurangnya pesanan. Melihat gejala ini perusahaan dituntut untuk lebih efektif dan efisien dalam proses pengelolaan informasi stok agar tidak terjadi kekurangan atau kelebihan stokyang menjadi penyebab utama kerugian perusahaan. Untuk mengatasi ini diperlukan satu bentuk desain sistem dengan tahapan-tahapan perancangan yang sistematis seperti rancangan sistem dalam bentuk use case diagram, rancangan basis data dalam bentuk class diagram, dan alur kerja sistem dalama bentuk sequence diagram dan activity diagram. Sehingga mampu memberikan suatu bentuk model aplikasi purchasing system untuk monitoring stok dalam mengurangi tingkat kerugian. Aplikasi ini diharapkan mampu memberikan manfaat secara efektif dan efisien dalam hal monitoring stok, proses penciptaan laporan dengan cepat dan akurat sehingga bisa mengurangi tingkat kerugian perusahaan, dengan cara menentukan batas minimal stok serta batas maximum stok setiap item barang yang disesuaikan dengan jumlah transaksi penjualan sesuai priode laporan.
\end{abstract}

Kata Kunci: Sistem Penjualan, Monitoring Stok, Tingkat Kerugian

\begin{abstract}
The rapid development of information technology is able to have a positive impact and accelerate the company's business growth quickly. Companies engaged in retail are increasingly being demanded to provide information quickly and precisely, especially things related to stock availability. The amount of stock that is reduced from the average need will cause the level of loss caused by the cancellation of orders or excess stock from the average sales also resulting in losses due to lack of orders. Seeing this symptom, companies are required to be more effective and efficient in the process of managing stock information so that there are no shortages or excess stocks which are the main causes of corporate losses. To overcome this we need a form of system design with systematic design stages such as system design in the form of use case diagrams, database designs in the form of class diagrams, and system workflows in the form of sequence diagrams and activity diagrams. So as to be able to provide a form of purchasing system application model for monitoring stocks in reducing the loss rate. This application is expected to be able to provide benefits effectively and efficiently in terms of stock
\end{abstract}


monitoring, the process of creating reports quickly and accurately so that it can reduce the level of loss of the company, by determining the minimum stock limit and maximum stock limit for each item according to the period report.

Keyword: Purchasing System, Inventory Control, Loss Rate

\section{PENDAHULUAN}

Perusahaan yang bergerak dibidang ritel semakin dituntut untuk memberikan informasi dengan cepat dan tepat, hal ini seiring dengan perkembangan teknologi informasi yang semakin pesat yang mampu memberikan dampak positif dan memacu pertumbuhan bisnis perusahaan.Tingkat kerugian yang disebabkan karena adanya pembatalan pesanan atau stok yang berlebih dari rata-rata penjualan biasanya disebabkan karena jumlah stok yang tidak sesuai dengan kebutuhan rata-rata penjualan.Hal ini merupakan penyebab terjadinyakerugian karena kurangnya pesanan. Melihat gejala ini perusahaan dituntut untuk lebih efektif dan efisien dalam proses pengelolaan informasi stok. Untuk mengatasi ini diperlukan bentuk desain sistem dengan tahap-tahapan perancangan yang sistematis seperti rancangan use case diagram, rancangan class diagram, rancangan sequence diagram dan rancangan activity diagram.

Hasil penelitian ini diharapkan dapat bermanfaat untuk menambah wawasan dan pengetahuan khususnya perusahaan yang bergerak dibidang distribusi dan penjulan dalam memonitoring persediaan barang untuk menhitung nilai jual efektif sehingga dapat meningkatkan penjualan dan menekan kerugian yang berdampak pada meningkatkan keuntungan.Selain itu juga diharapkan dapat memberikan informasi dan gambaran jelas lainnya yang berhubungan dengan masalah ini.Hasil penelitian ini dapat menjadikan sarana atau rekomendasi bagi manajemen perusahaan agar dapat mengelola persediaan barang secara lebih baik dan dapat meningkatkan nilai jual sehingga dapat menghindari resiko yang tidak diinginkan.

\section{METODE PENELITIAN}

\section{Metode Observasi (Observasi Research)}

Pada tahapan ini penulis melakukan pengamatan langsung dari objek penelitian untuk medapatkan data dan informasi yang akurat dan lengkap dari berbagai pihak yang terkait dan berhubungan dengan tema penelitian yang berhasil penulis rumuskan dibagian pembelian.Penulis melakukan wawancara Purchasing dan Gudang yang mengelola data pembelian, penulis mendapatkan informasi terkait dengan penelitian penulis.Selain melakukan observasi penulis juga melakukan data dengan cara studi pustaka dalam metode ini penulis berusaha untuk melengkapi data-data yang diperoleh dengan membaca dan mempelajari dari buku-buku dan data-data yang relavan dalam pemilihan judul yang penulis ajukan. Buku dan data tersebut digunakan penulis untuk membantu penganalisaan dan perancangan yang dilakukan.

\section{Metode Analisa Data}

Pada penelitian ini, metode analisa data dilakukan dengan langkah-langkah melakukan pengamatan dan analisa terhadap sistem yang berjalan saat ini, serta menentukan UML (Unified Modeling Language) yang meleiputi use case diagram, activity diagram, sequence diagram. 


\section{PEMBAHASAN}

Untuk dapat menggambarkan prosedur secara keseluruhan diperlukan beberapa tahapan analisa sebagai bentuk pengumpulan informasi guna mendapatkan model yang sesuai kebutuhan dan mampu memberikan solusi dengan cepat secara efektif dan efisien, mulai tahapan pengumpulan informasi dan kebutuhan, analisa dokumen, merancang hubungan antar dokumen sampai dengan merancang model diagram database dan model rancangan sistem.

\section{Use Case Diagram Prosedur Berjalan}

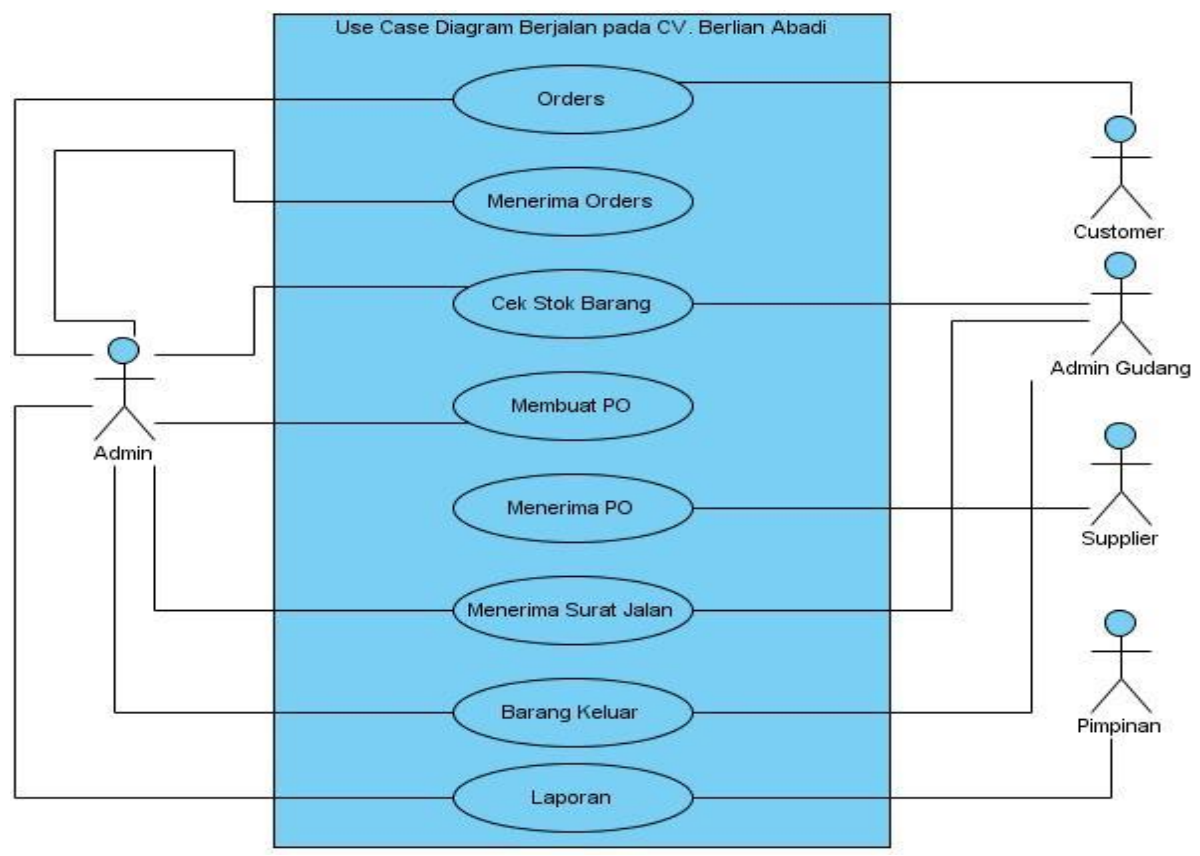

Gambar 1. Use Case Diagram

Berdasarkan usecase diagram (gambar 1) terlihat ada 5 (lima) aktor yaitu customer, admin, supplier, admin gudang, pimpinan. Dimana customer memberikanorders sebagai bentuk pesanan barang, yang kemudian akan ditangani oleh admin. Kemudian berdasarkan orders tersebut admin melakukan pengecekan stok barang, jika jumlah barang yang dipesan belum memenuhi orders maka admin melakukan kegiatan pembelian barang dengan membuat purchase order (po) sebagai surat pemesanan barang yang kemudian dikirim ke supplier. Kemudian berdasarkan purchase order(po) tersebut supplier akan mengirimkan barang beserta dokumen terkait, seperti surat jalan, faktur yang akan diterima admin gudang sebagai bentuk serah terima barang dari supplier masuk ke gudang,dilanjutkan dengan proses penginputan dokumen po, surat jalan yang dikirim dari supplier, dan barang masuk. kemudian admin akan menginput orders dari customer sebagai bentuk barang keluar yang kemudian akan dijadikan sebagai laporan ke pimpinan. 


\section{Activity Diagram}

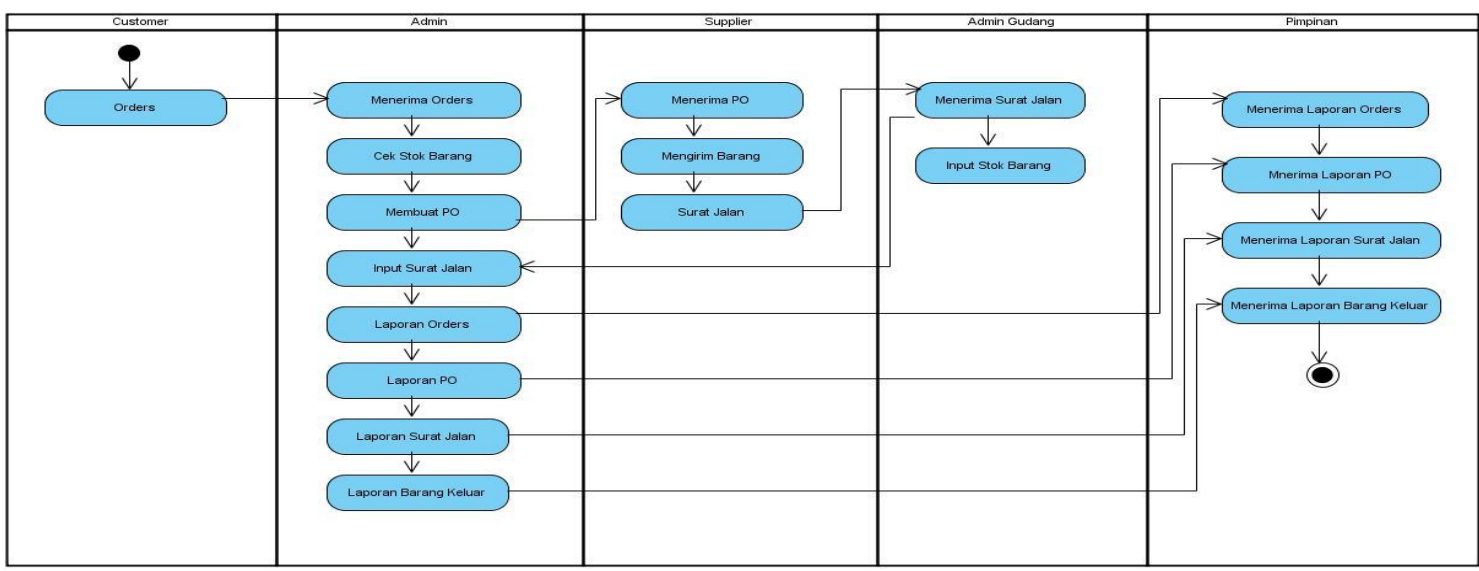

Gambar 2. Activity Diagram

Berdasarkan gambar activity diagram (gambar 2) sistem ini terdapat 5 (lima) kolom, dimana setiap kolom mewakili satu aktor,yaitu customer, admin, supplier, admin gudang, pimpinan. Berdasarkan activity diagram tersebut orders yang dikirim dari customer akan diterima oleh admin, kemudian admin cek stok barang, jika barang yang dipesan customer jumlahnya belum memenuhi maka admin akan membuat pesanan untuk supplier dengan membuat po, gudang akan menerima barang yang dikirim dari supplier berdasarkan dokumen terkait yaitu surat jalan, faktur sebagai bukti barang masuk dari supplier, adminakan menginput pembelianberdasarkan dokumen surat jalan dari supplier dan barang masuk dari gudang, admin juga menginput orders berdasarkan dokumen orders. Stok barang dan barang keluar yang dijadikan sebagai laporan ke pimpinan,

\section{Sequence Diagram Prosedur Usulan}

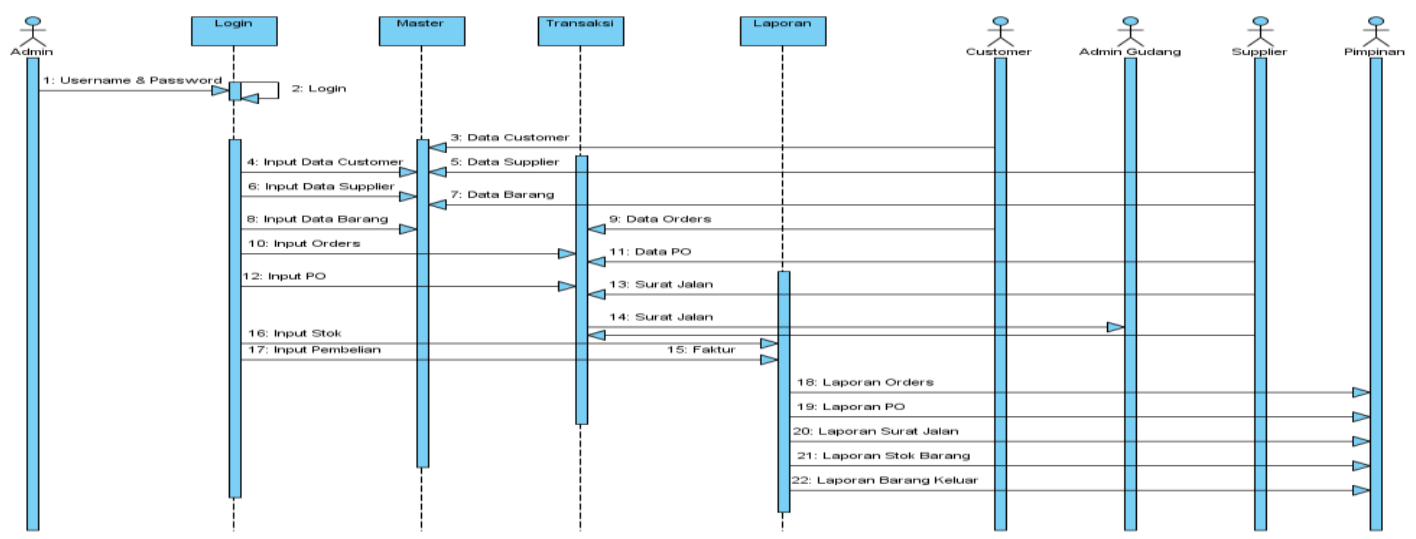

Gambar 3. Sequence Diagram

Berdasarkan gambar sequence diagram (gambar 3) sistem terlihat 5 (lima) actor yang melakukan kegiatan diantaranya: customer ,admin, admin gudang, supplier,pimpinan.yang akan menyelasikan 22message spesifikasi dari komunikasi dari komunikasi agar objek yang akan memuat informasi-informasi tentang aktifitas yang terjadi, yaituusername dan password untuk login, data customer, input data customer, 
data supplier, input data supplier,data barang, input data barang, data orders, input data orders, data po,input data po,surat jalan,faktur, input stok barang,data barang keluar, input barang keluar, input laporan yaitu laporan orders, laporan po, laporan surat jalan, laporan stok barang,laporan barang keluar.

\section{Class Diagram}

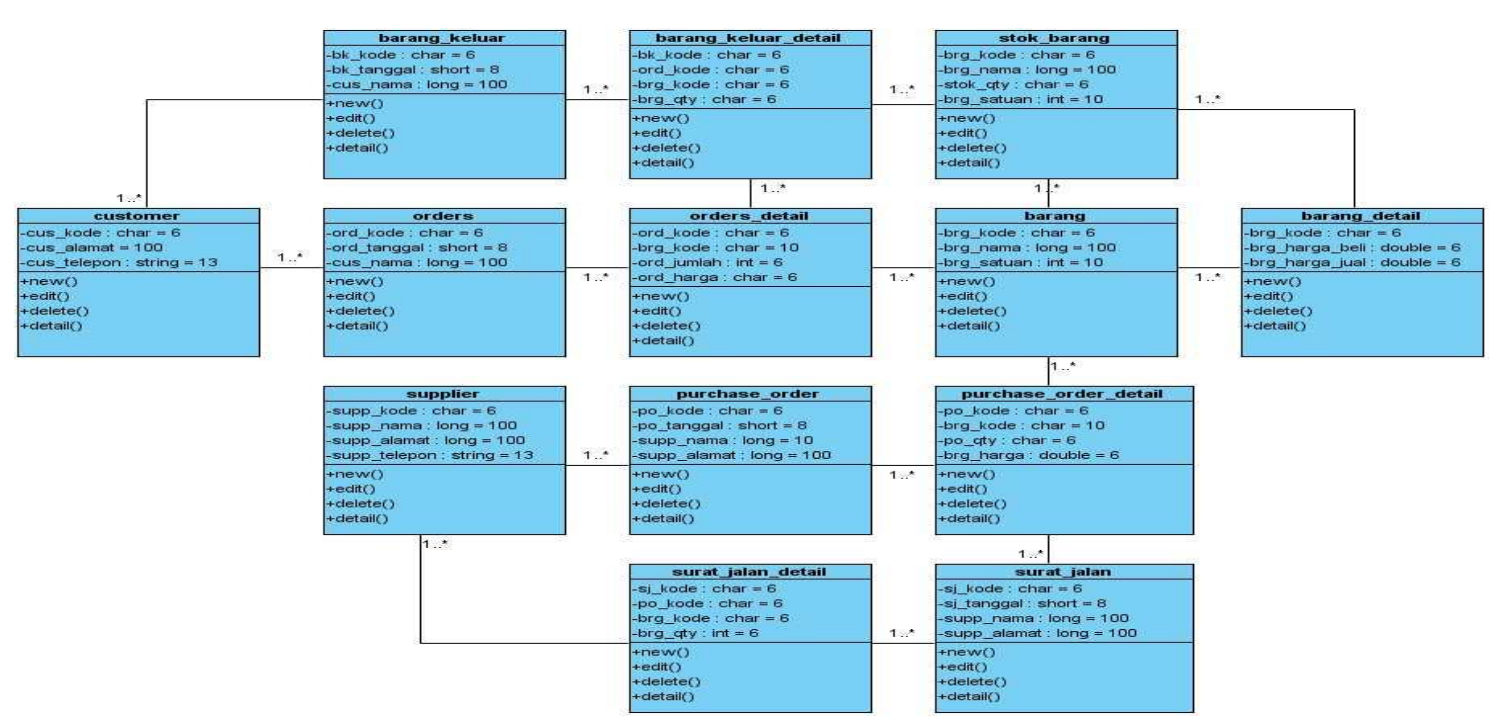

Gambar 4. Class Diagram

Berdasarkan gambar class diagram (gambar 4) yang usulan sistem yang mencangkup seluruh kegiatan pada sistem pembelian. Terdapat 13 (tiga belas) class yaitu customer, supplier, barang yang merupakan tabel master dan orders, purchase_order, surat_jalan, stok_barang, barang_keluartercipta karena adanya tabel orders, tabel purchase_order_detail tercipta adanya tabel purchase_order, tabel surat_jalan_detail tercipta adanya tabel surat_jalan dan merupakan tabel histori.

Berdasarkan gambar class diagram (gambar 4) diatas dapat dilihat dengan jelas bahwa tingkat hubungan customerdan orders yaitu one to many (1:M), tingkat hubungan orders dan orders_detail yaitu one to many (1:M), orders_detail dengan tabel barang yaitu one to many (1:M), tabel stok_barang dengan tabel barang yaitu one to many (1:M), tabel purchase_order dengan tabel purchase_order_detail one to many (1:M), tabel purchase_order_detail dengan barang yaitu one to many $(1: \mathrm{M})$, tabel supplier dengan tabel purchase_order yaitu one to many $(1: \mathrm{M})$, tabel purchase_order dengan tabel surat_jalan yaitu one to many (1:M), tabel surat jalan dengan tabel surat_jalan_detail yaitu one to many (1:M).tabel orders_detail dengan barang_keluar_detail one to many (1:M), tabel barang_keluar dengan tabel customer one to many (1:M).

Berdasarkan gambar class diagram (gambar 4) masing-masing tabel memiliki sebuah field sesuai kebutuhnya seperti tabel customer yang terdiri dari field cs_kode, cs_alamat, cs_telepon dimana cs_kode merupakan primary key (pk) dari tabel customer. Tabel supplier yang terdiri dari field supp_kode, supp_nama, supp_alamat, supp_telepon dimana supp_kode merupakan primery key (pk).Tabel barang yang terdiri dari field brg_kode, brg_nama_barang, brg_satuan, dimana br_kode merupakan primary key (pk).Tabel orders yang terdiri dari field ord_kode, ord_tanggal dimana ord_orders 
merupakan primery key (pk),tabel stok_barang yang teridiri dari brg_kode, brg_nama, stok_qty, btg_satuan dimana ord_kode merupakan primary key (pk). Tabel purchase_order yan teridiri dari po_kode, po_tanggal,sup_nama, sup_alamat dimana po_kode merupakan primary key (pk). Tabel surat_jalan terdiri dari sj_kode,sj_tanggal, sup_nama,sup_alamat dimana sj_kode merupakan primary key (pk).Tabel barang_keluar yang teridiri dari bk_kode, bk_tanggal, cus_nama dimana bk_kode merupakan primary key (pk).Kemudian juga terdapat field orders_detail yang merupakan foreign key (fk) dari tabel orders, purchase_order_detail yang merupakan foreign key (fk) dari tabel purchase_order, surat_jalan_detail yang merupakan foreign key (fk) dari tabel barang dan tabel surat_jalan, tabel barang_keluar_detail yang merupakan foreign key (fk) dari tabel barang_keluar.

\section{Use Case Diagram Usulan}

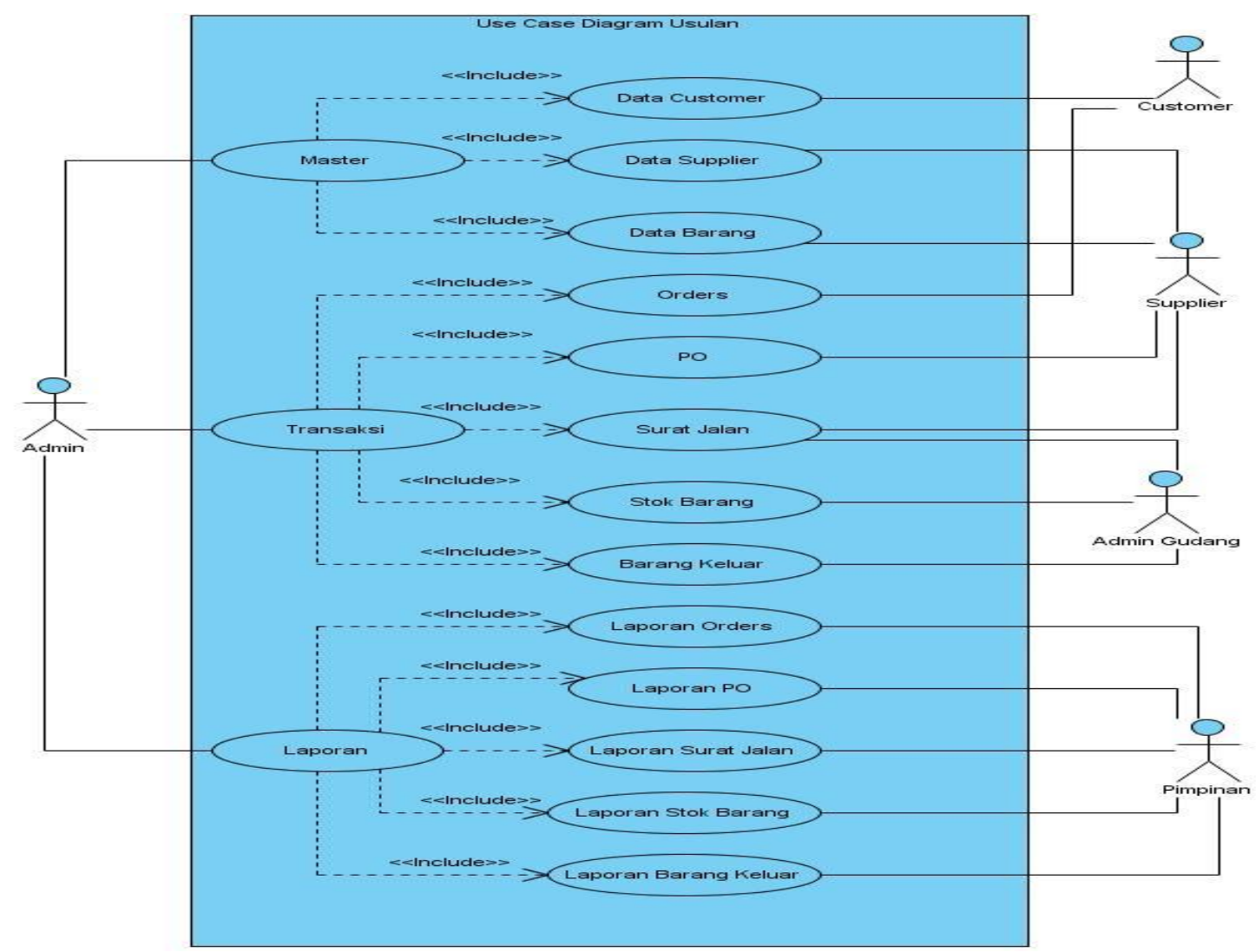

Gambar 5. Use Case Diagram Usulan

Berdasarkan gambar use case diagram usulan (gambar 5) terlihat jelas bahwa terdapat 5 (lima) aktor yaitu admin, customer, supplier, admin gudang, dan pimpinan. Terdapat 10 use case (sepuluh) use case yang terdiri dari 3 (tiga) use case utama yaitu master, transaksi, laporan. Use case master memiliki 3 (tiga) yang terdiri dari user yang terhubung dengan aktor customer, dan aktor supplier. Use case transaksi memiliki (lima) yang terdiri dari orders, po, surat jalan, stok barang, barang keluar yang terhubung dengan aktor admin, aktor customer, aktor supplier, aktor admin gudang. Use cas laporan memiliki 5 (lima) yang terdiri dari laporan orders, laporan po, laporan surat jalan, laporan stok barang, laporan barang keluar yang terhubung dengan aktor admin dan aktor pimpinan. 


\section{IMPLEMENTASI}

\section{Rancangan Basis Data}

Untuk dapat menggambarkan bentuk basis data secara utuh, peniliti menggunakan aplikasi Microsoft access sebagai bentuk gambaran dasar, dan pada akhirnya bentuk rancangan basis data ini dapat disesuaikan menggunakan apa saja sesuai kebutuhan.

\section{Tabel 1. Master Customer}

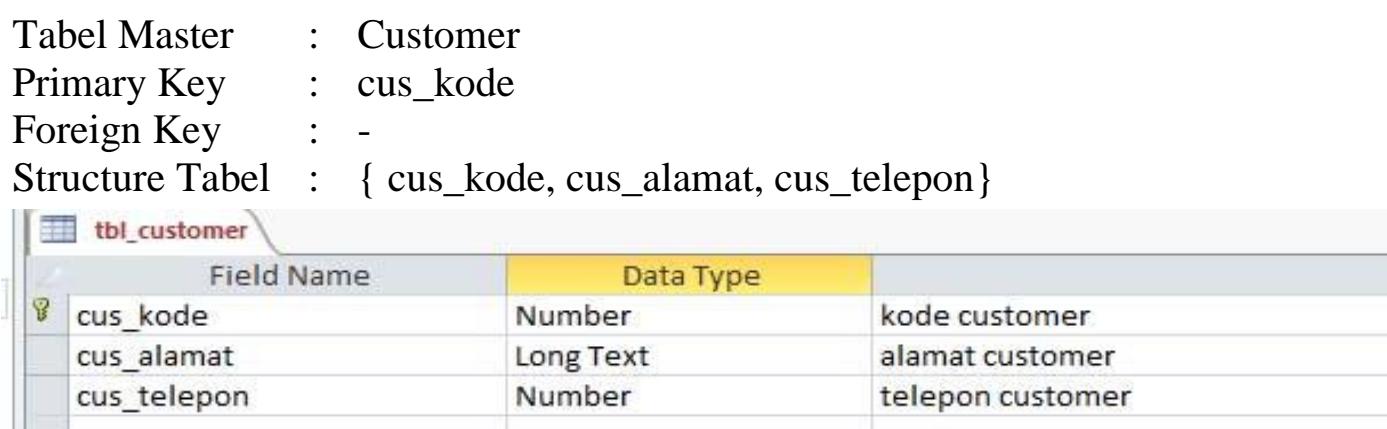

Tabel 2. Master Barang

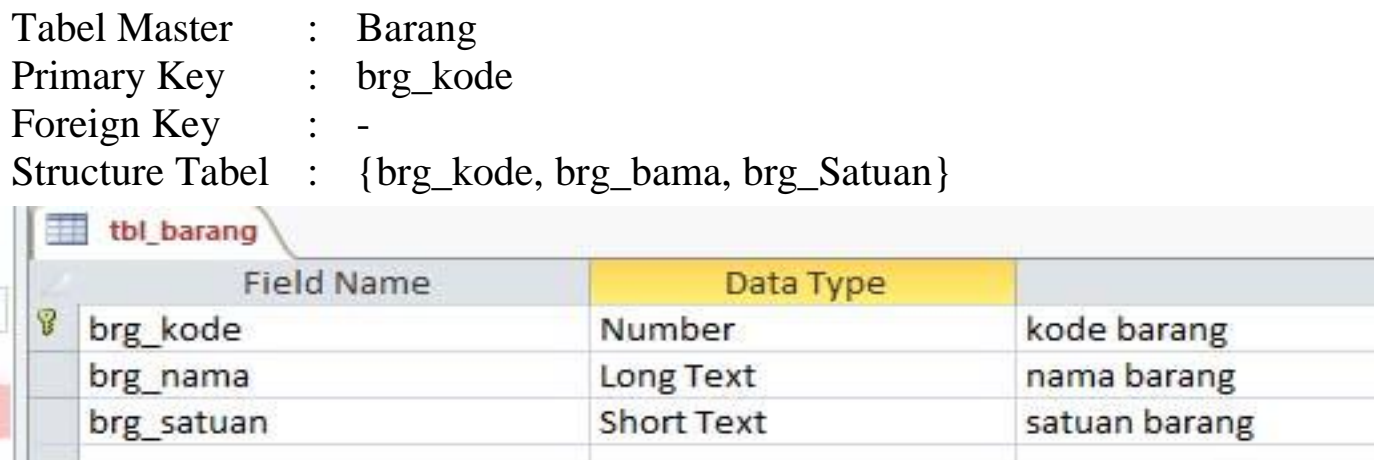

Tabel 3. Master Supplier

Tabel Master : Supplier

Primary Key : supp_kode

Foreign Key : -

Structure Tabel : \{supp_kode, supp_nama, supp_alamat, supp_telepon

\begin{tabular}{|c|c|c|c|}
\hline & Field Name & Data Type & \\
\hline \multirow[t]{4}{*}{8} & supp_kode & Number & kode supplier \\
\hline & supp_nama & Long Text & nama supplier \\
\hline & supp_alamat & Long Text & alamat supplier \\
\hline & supp_telepon & Long Text & telepon supplier \\
\hline
\end{tabular}


Tabel 4. Transaksi Order

Tabel Transaksi : Orders

Primary Key : ord_kode

Foreign Key : -

Structure Tabel : \{ord_kode, ord_tanggal, cus_nama

\begin{tabular}{|l|l|l|}
\hline \multicolumn{1}{|c|}{ Field Name } & \multicolumn{1}{c}{ Data Type } & \\
\hline ord_orders & Number & kode orders \\
\hline $\begin{array}{l}\text { org_tanggal } \\
\text { cus_nama }\end{array}$ & Short Text & tanggal orders \\
\hline & Long Text & nama customer \\
\hline
\end{tabular}

Tabel 5. Transaksi Purchase Order

Tabel Transaksi : purchase_order

Primary Key : po_kode

Foreign Key : po_kode, supp_nama

Structure Tabel : \{po_kode, po_tanggal, supp_nama, supp_alamat

\begin{tabular}{|c|c|c|c|}
\hline & Field Name & Data Type & \\
\hline 8 & po_kode & Number & kode po \\
\hline & po_tanggal & Short Text & tanggal po \\
\hline & supp_nama & Long Text & nama supplier \\
\hline & supp_alamat & Long Text & alamat supplier \\
\hline
\end{tabular}

Tabel 6. Transaksi Surat Jalan

Tabel Transaksi : surat_jalan

Primary Key : sj_kode

Foreign Key : -

Structure Tabel : $\{$ sj_kode, sj_tanggal, supp_nama, supp_alamat $\}$

\begin{tabular}{||l|l|l|}
\hline \multicolumn{1}{c}{ Field Name } & \multicolumn{2}{c}{ Data Type } \\
\hline tbj_surat jalan & Number & kode surat jalan \\
\hline sj_tanggal & Number & tanggal surat jalan \\
\hline supp_nama & Long Text & nama supplier \\
\hline supp_alamat & Long Text & alamat supplier \\
\hline
\end{tabular}

Tabel 7. Transaksi Stok Barang

Tabel Transaksi : stok_barang

Primary Key : brg_kode

Foreign Key : -

Structure Tabel : \{brg_kode, brg_nama, stok_qty, brg_satuan 


\begin{tabular}{|l|l|l}
\hline \multicolumn{2}{|c|}{ Field Name } & \multicolumn{2}{c}{ Data Type } \\
\hline 8 brg_kode & Number & kode barang \\
\hline brg_nama & Number & nama barang \\
\hline stok_qty & Number & jumlah stok \\
\hline brg_satuan & Number & satuan barang \\
\hline
\end{tabular}

Tabel 8. Transaksi Barang Keluar

Tabel Transaksi : barang_keluar

Primary Key : bk_kode

Foreign Key : bk_kode, cus_nama

Structure Tabel : \{bk_kode, bk_tanggal, cus_nama $\}$

\section{Diagram HIPO}

Untuk menggambarkan struktur menu dari sistem yang dirancang dapat digambarkan dengan diagram HIPO (Hierarchy Input Process Output) untuk menyediakan suatu struktur guna memahami fungsi-fungsi dari program.

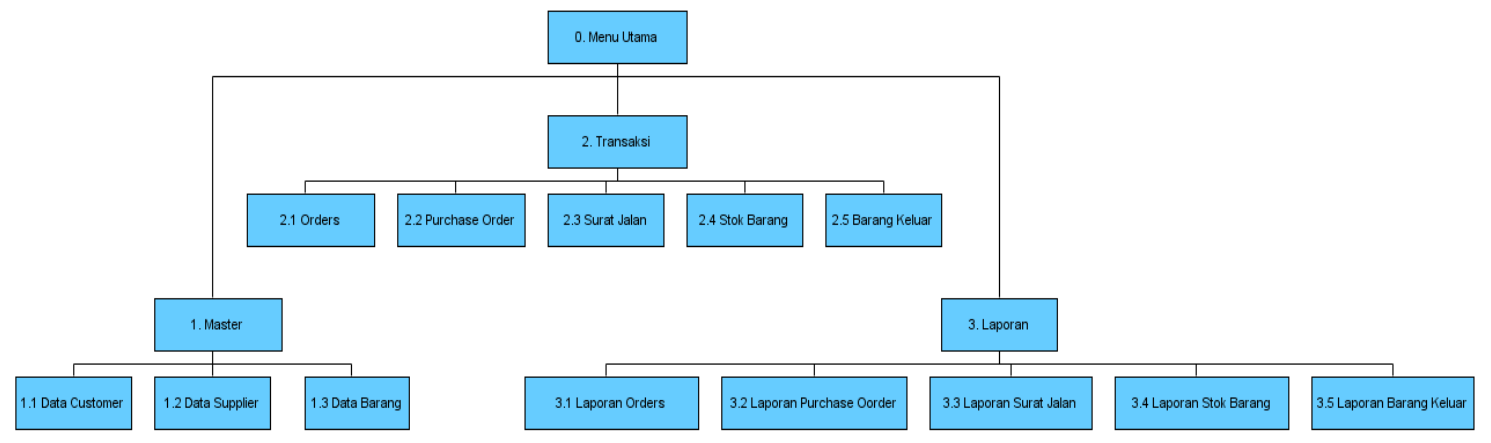

Gambar 6. Diagram HIPO

Terlihat dari diagram HIPO diatas (gambar 6) terdapat 1 (satu) fungsi utama (diagram 0) dan 3 (tiga) fungsi dibawahnya, yaitu fungsi master (diagram 1), menu transaksi (diagram 2) dan menu laporan (diagram 3). Didalam fungsi menu master (diagram 1) terdapat 3 (tiga) fungsi sub menu yaitu menu customer (diagram 1.1). data supplier (diagram 1.2), dan data barang (diagram1.3). Didalam fungsi menu transaksi (diagram 2) terdapat 5 (lima) fungsi fungsi sub menu yaitu fungsi menu orders (diagram 2.1), purchase order (diagram 2.2), surat jalan (diagram 2.3), stok barang (diagram 2.4), dan barang keluar (diagram 2.5). Didalam fungsi laporan (diagram 3) terdapat 5(lima) fungsi sub menu yaitu fungsi menu laporan orders (diagram 3.1), menu laporan 
purchase order (diagram 3.2), menu surat jalan (diagram 3.3), menu laporan stok barang (diagram 3.4), dan menu barang keluar (diagram 3.5)

\section{Rancangan Tampilan}

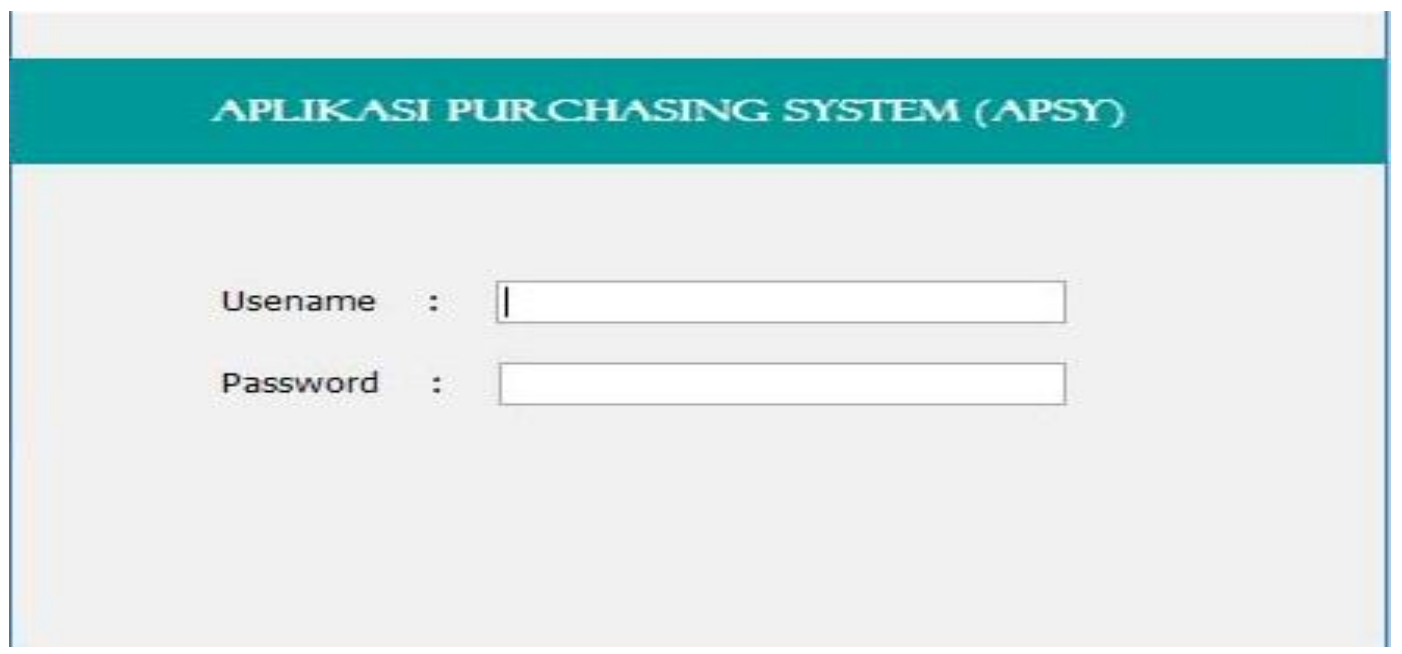

Gambar 7. Rancangan Layar Login

Terlihat gambar diatas (gambar 7) merupakan rancangan layar untuk menu login, proses ini dilakukan dengan memasukkan username dan password yang sudah didaftarkan.

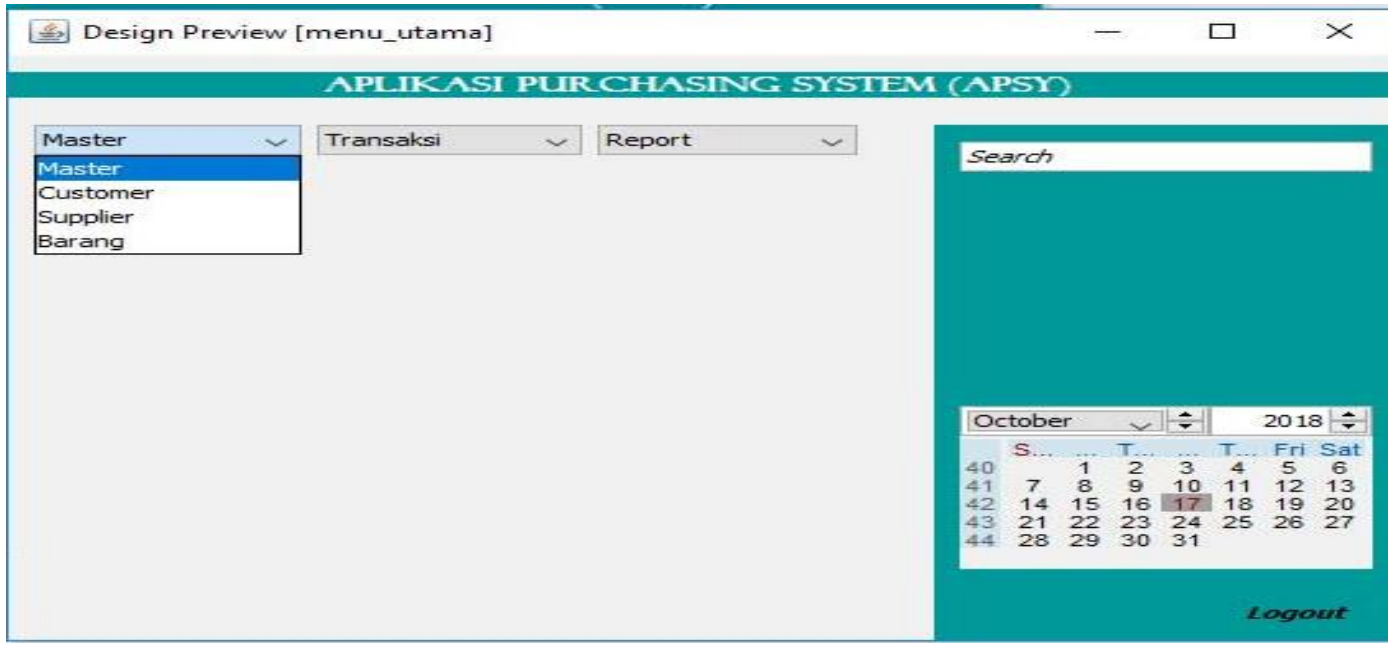

Gambar 8. Rancangan Layar Menu Utama

Terlihat gambar diatas (gambar 8) merupakan rancangan layar utama, proses ini dilakukan dengan memasukkan username dan password yang sudah didaftarkan, dan ketika berhasil masuk maka layar ini akan ditampilkan untuk pertama kalinya. Layar utama ini terdiri dari 3 menu utama yaitu menu master, menu transaksi dan menu laporan. Kemudian didalam menu master terdapat sub menu customer, sub menu supplier dan sub menu barang. 


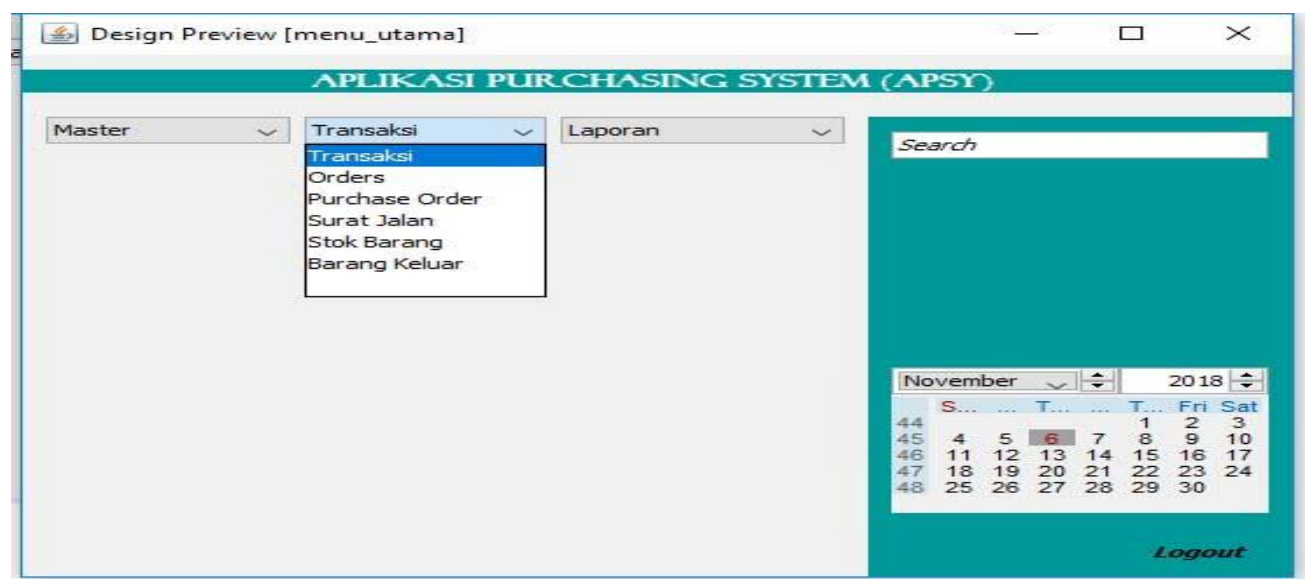

Gambar 9. Rancangan Layar Menu Transaksi

Terlihat gambar diatas (gambar 9) merupakan rancangan layar menu master, menu transaksi ini terdiri dari 5 sub menu yaitu sub menu order, sub menu purchase order, sub menu surat jalan, sub menu stok barang dan sub menu barang keluar.

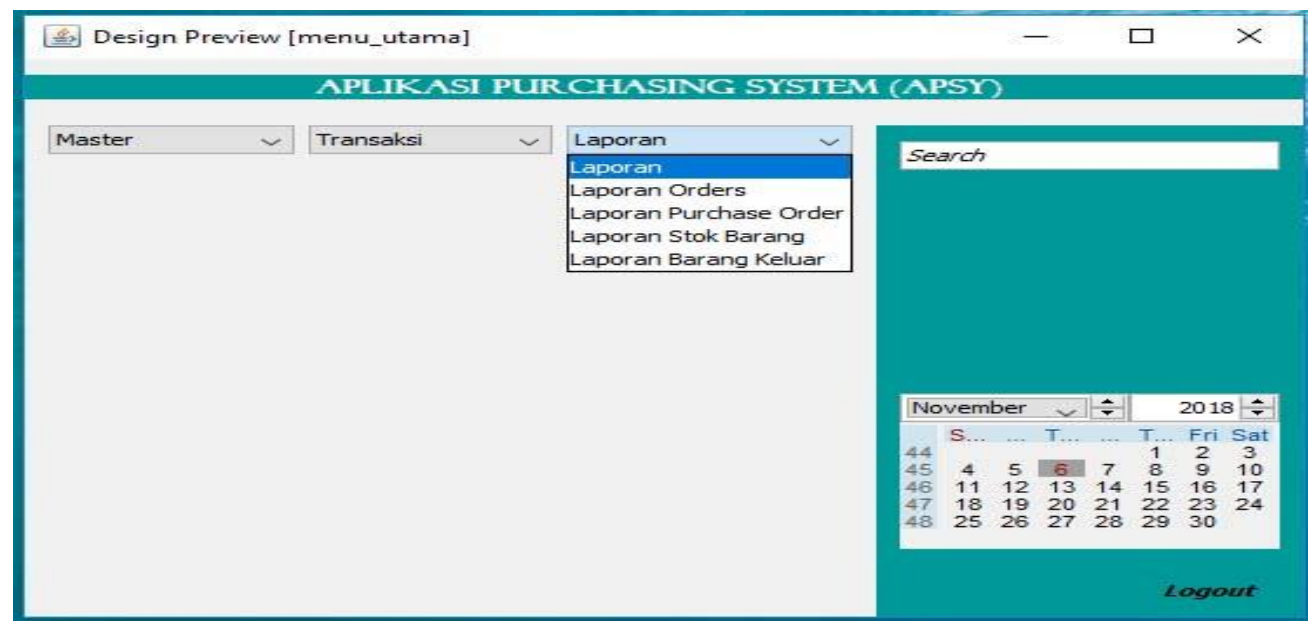

Gambar 10. Rancangan Layar Menu Laporan

Terlihat gambar diatas (gambar 10) merupakan rancangan layar menu laporan, menu laporan ini terdiri dari 4 sub menu yaitu sub laporan orders, sub menu lporan purchase order, sub menu stok jalan, sub menu barang keluar.

\section{Grafik Monitoring Stok Barang}

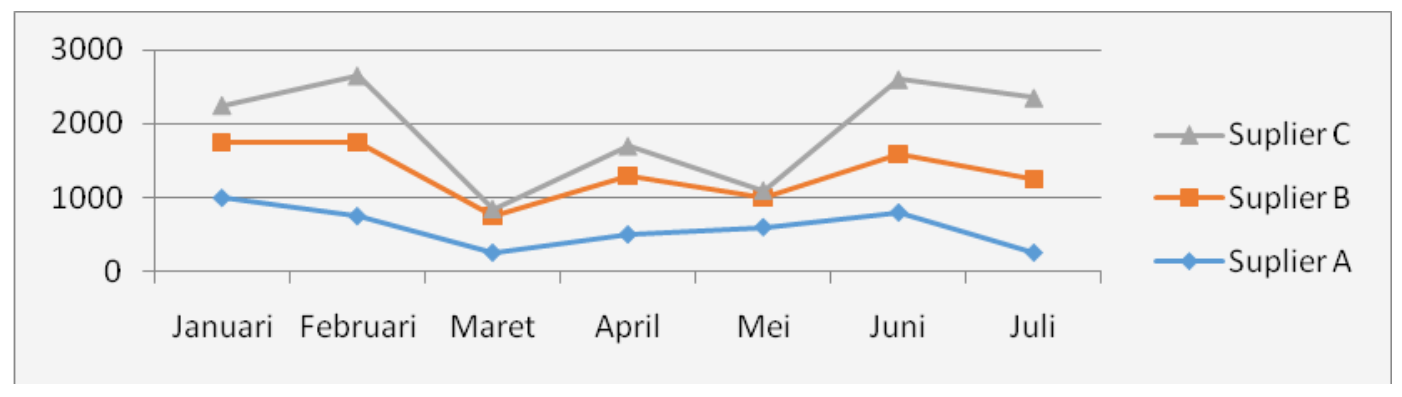

Gambar 11. Diagram HIPO 
Grafik diatas (gambar 11) merupakan grafik monitoring stok barang berdasarkan waktu (bulan). Hal ini bisa membantu monitoring dalam mengurangi tingkat kerugian.

\section{KESIMPULAN}

Proses penjualan yang selama ini berjalan masih dilakukan secara manual, dengan mengginakan dokumen penjualan, demikian juga halnya dengan pencatatan daftar barang serta jumlah barang yang ada digudang. Karena proses yang menual ini, terkadang meninbulkan beberapa permasalahan, mulai dari tidak akuratnya data dan lambatnya proses pencarian maupun perhitungan jumlah stok, sehingga berdampak pada kerugian. Model purchasing yang diusulkan ini mampu mengatasi permasalahan diatas, dan mampu memonitoring jujlah stok secara cepat, juga meningkatkan akurasi serta menghindari human error. Dengan model ini dapat membantu perusahaan untuk mengurangi tinkat kerugian akibat tidak tersedianya stok atapun akibat melimpahnya setok karena kadaluars. Dalam model ini juga ditambahkan suatu konsep penentuan minimal stok dan penentuan maksimal stok, banyaknya jumlah minimal stok atau jumlah maksimal stok sangat tergantung dari tingkat penjualan masing masing barang, juga bisa dihubungkan dengan musim tertentu yang berpengaruh terhadap meningkat atau berkurangnya permintaan barang.

\section{DAFTAR PUSTAKA}

[1] Junaidi, Junaidi, Sugeng Santoso, and Lusyani Sunarya. "Rekayasa Teknik Pemrograman Pencegahan Dan Perlindungan Dari Virus Lokal Menggunakan API Visual Basic." CCIT Journal 1.2 (2008): 134-153.

[2] Rijan, Yunirman, and Ira Koesoemawati. "Cara Mudah Membuat Surat Perjanjian/Kontrak dan Surat Penting Lainnya." Raih Asa Sukses, Depok (2009).

[3] Junaidi, Junaidi, Abdul Roji, and Kharis Munawar. "Konsep Otomatisasi Sistem Pembayaran SPP Online Untuk Mengurangi Tingkat Keterlambatan." Proceedings Konferensi Nasional Sistem dan Informatika (KNS\&I) (2015).

[4] Sugianto. 2013. "Perancangan Sistem Informasi Penjualan Pada Butik Luwes Fashion Kecamatan Tulakan." Indonesian Jurnal on Computer Science-Speed (IJCSS) Vol 2 No 1 ISSN:2302-1136 (2013).

[5] Junaidi, Junaidi, Ladyca Anugrah, and Adhitya Dwi Pancasakti. "Model Aplikasi Monitoring Sistem Absensi Sidik Jari Sebagai Pendukung Keputusan Untuk Penilaian Kinerja Pegawai." Proceedings Konferensi Nasional Sistem dan Informatika (KNS\&I) (2015).

[6] Junaidi, Junaidi, Ridwan Arifin, and Amanda Septiani. "Rancang Bangun Aplikasi Sistem Inventory Berbasis Desktop Menggunakan JSE." Proceedings Konferensi Nasional Sistem dan Informatika (KNS\&I) (2015).

[7] Junaidi, Junaidi, Novi Cholisoh, and Nur Hasanah. "Rancang Bangun Sistem Manajemen Aset IT Untuk Pencatatan History Maintenance Sebagai Pendukung Keputusan." SENSI Journal 4.2 (2018): 220-231.

[8] Henderi, Henderi, Junaidi Junaidi, and Tubagus Ahmad Harja Kusuma. "Dashboard Monitoring System Penjualan Dan Reward Mobile Kios PT. Telekomunikasi Seluler." Semantik 2.1 (2012). 
[9] Junaidi, Junaidi, Retno Setianingsih, and Khusnul Khotimah. "Rancang Bangun Sistem Penerimaan Dan Pengeluaran Barang Menggunakan Java Aplikasi." Proceedings Konferensi Nasional Sistem dan Informatika (KNS\&I) (2015).

[10] Junaidi, Junaidi, Abdul Roji, and Kharis Munawar. "Konsep Otomatisasi Sistem Pembayaran SPP Online Untuk Mengurangi Tingkat Keterlambatan." Proceedings Konferensi Nasional Sistem dan Informatika $(K N S \& I)(2015)$. 